\author{
I.С. Кравчук ${ }^{1}$, О.І. Сподін ${ }^{1}$, В.І. Нікітченко ${ }^{2}$, В.Г. Березанський ${ }^{3}$ \\ ${ }^{1}$ Товариство з обмеженою відповідальністю “Науково-виробнича фірма “Адрон”, Київ \\ 2 Держсавний науково-дослідний інститут випробувань і сертифікації озброєння \\ та військової техніки, Чернігів \\ ${ }^{3}$ Харківський національний університет Повітряних Сил ім. І. Кожедуба, Харків
}

\title{
ОБҐРУНТУВАННЯ ПАРАМЕТРІВ ХИБНИХ ТЕПЛОВИХ ЦІЛЕЙ ДЛЯ ЗАХИСТУ ЛІТАЛЬНИХ АПАРАТІВ ВІД КЕРОВАНИХ РАКЕТ 3 ІНФРАЧЕРВОНИМ САМОНАВЕДЕННЯМ
}

\begin{abstract}
Стаття присвячена обтрунтуванню вимог до сучасних хибних теплових ичілей для захисту літальних апаратів від керованих ракет з інфрачервоним самонаведенням. Так, для імітування просторових, енергетичних та траєкторних ознак повітряної цілі відстрілювання хибних теплових иілей виконується у вигляді комбінованих залпів, у яких хибні теплові иілі мають різну потужність інфрачервоного випромінювання, різні коефічієнти лобового опору, завдяки чому швидкість гальмування зустрічним повітряним потоком у них різна, а часові інтервали відстрілювання окремих хибних теплових иілей у залпі підбираються таким чином, щзоб амплітудні, спектральні та траєкторні селектори сучасних інфрачервоних головок самонаведення не змогли однозначно виконати селекцію. Підтверджено, щзо однією з основних характеристик хибних теплових иілей, яка визначає ї̈ ефективне застосування для захисту літальних апаратів від керованих ракет з інфрачервоним самонаведенням, є максимальна або пікова сила випромінювання у заданому діапазоні довжин хвиль. Також в статті розглянуто один з нових способів застосування хибних теплових иілей та вимоги до них. Зокрема, обгрунтовані вимоги до закону зміни інфрачервоного випромінювання у часі, необхідної сили інфрачервоного випромінювання, часу виходу на режим та досягнення ефективного рівня випромінювання, а також повного часу випромінювання.
\end{abstract}

Ключові слова: хибна теплова ијіль, літальний апарат, сила випромінювання, магній-тефлон-вітон, час виходу на режим, закон зміни випромінювання.

\section{Вступ}

Постановка проблеми. Найбільш ефективними та поширеними засобами боротьби з літаками, вертольотами і іншими повітряними об'єктами при веденні бойових дій у теперішній час стали керовані ракети класів “повітря - повітря" та "поверхня повітря" з інфрачервоним (ІЧ) самонаведенням.

Серед навмисних оптичних завад для протидії керованим ракетам з ІЧ головками самонаведення (ГСН) найбільшого поширення зазнали хибні теплові цілі (ХТЦ), що являють собою джерела ІЧ випромінювання, найчастіше піротехнічні, які у процесі протидії відділяються (відстрілюються) від ЛА 3 метою відведення від них атакуючих ракет на безпечну відстань. Широкому поширенню ХТЦ сприяють такі фактори, як їх дешевизна, простота та висока ефективність захисту. ХТЦ постійно вдосконалюються у напрямках покращення їх енергетичних параметрів та підвищення ефективності захисту ЛА від ракет з ІЧ ГСН. На сьогоднішній день практично всі ЛА військового призначення оснащені засобами застосування ХТЦ. Тому питання обгрунтування вимог до сучасних та перспективних ХТЦ є актуальними.
Аналіз останніх досліджень і публікацій. Питанням розвитку піротехнічних ХТЦ присвячена значна кількість публікацій, наприклад [1-4].

У даних публікаціях, в основному, розглядаються питання вдосконалення хімічного складу ХТЦ та способів їх застосування. Але у відомих публікаціях практично не розглядаються питання, що стосуються обгрунтування енергетичних та часових параметрів випромінювання ХТЦ.

Мета статті - обгрунтування вимог до закону зміни ІЧ випромінювання у часі, необхідної сили ІЧ випромінювання, часу виходу на режим та досягнення ефективного рівня випромінювання і також повного часу випромінювання сучасних зразків ХТЦ.

\section{Виклад основного матеріалу}

Самонаведення керованих ракет за допомогою ІЧ ГСН знайшло широке застосування в авіаційних ракетних комплексах класу “повітря-повітря" та зенітно-ракетних комплексах протиповітряної оброни ближньої та малої дальності дії, у тому числі в переносних зенітних ракетних комплексах (ПЗРК).

Практично всі сучасні ІЧ ГСН містять у своєму складі засоби (схеми, блоки, пристрої) селекції, ос- 
новним призначенням яких є захист від дії навмисних оптичних завад, серед яких найбільш поширеними є ХТЦ. Найчастіше ознаками, що використовуються для селекції реальної цілі від ХТЦ, є параметри їх відносного руху (траєкторні ознаки), параметри інтенсивності ІЧ випромінювання (енергетичні ознаки), розподіл інтенсивності ІЧ випромінювання за спектром (спектральні ознаки).

Поява ХТЦ у полі зору ІЧ ГСН призводить до різкої зміни інтенсивності оптичного сигналу, що використовується як ознака початку дії ХТЦ на ІЧ ГCH.

Інформацію про відносний рух цілі та ХТЦ отримують на основі аналізу кутової швидкості лінії візування цих об'єктів. Так, ХТЦ, у яких не використовуються спеціальні пристрої для зміни їх кінематичних параметрів, після відстрілювання швидко уповільнюються навколишнім повітряним середовищем. Якщо зміна кутової швидкості лінії візування об'єкта у полі зору ІЧ ГСН перевищує заданий поріг, то приймається рішення, що цей об'єкт - ХТЦ, після чого виконуються заходи щодо поновлення слідкування за ціллю.

Для розрізнення цілі та ХТЦ за спектральними ознаками застосовують спектральні селектори, які аналізують випромінюючий об'єкт не менш, ніж у двох роздільних спектральних смугах, наприклад у короткохвильовому та середньохвильовому діапазонах довжин хвиль.

Досить часто для реалізації алгоритмів завадозахищеності в ІЧ ГСН останніх поколінь застосовують метод слідкування за “найближчим".

Цей метод полягає у тому, що у кожному періоді сканування запам'ятовують поточні амплітуду сигналу та координати, що відповідають повітряній цілі. Маючи на увазі, що амплітуда сигналу та координати ХТЦ змінюються набагато швидше, ніж ці ж параметри повітряної цілі, при появі у полі зору ІЧ ГСН двох джерел ІЧ випромінювання, за ціль приймається джерело, амплітуда сигналу та координати якого найближчі до значень, що були у попередньому періоді сканування.

Наведені засоби і способи селекції ефективно захищають ІЧ ГСН від дії ХТЦ, що відстрілюються одиночно, або серіями одиночних ХТЦ з інтервалами, що складають одиниці і більше секунд. Якщо інтервали між відстрілюваними ХТЦ стають менші ніж час, який необхідний для виконання циклу селекції, ефективність захисту ІЧ ГСН від дії ХТЦ різко знижується.

Таким чином, ключем до суттєвого підвищення ефективності захисту ЛА за допомогою ХТЦ є вдосконалення способів їх застосування. У сучасних комплексах захисту ЛА від керованих ракет з ІЧ ГСН спостерігається перехід до масового відстрілювання ХТЦ у вигляді залпів, коли ІЧ випромінюван- ня цілі “розчиняється” на фоні однієї або кількох “хмар” хибних випромінювачів [3].

Такий спосіб застосування ХТЦ є досить ефективним, але вимагає великої їх кількості на борту ЛА.

Відомий також інший підхід до захисту ЛА від керованих ракет з ІЧ ГСН за допомогою ХТЦ [4].

У відповідності до цього підходу замість поодиноких відстрілювань ХТЦ, що створюють поодинокі джерела ІЧ випромінювання, формуються просторово розподілені ІЧ випромінювачі, які утворені деякою групою ХТЦ для “відволікання” ІЧ ГСН від реальної повітряної цілі. Така група ХТЦ формує просторово та енергетично розподілений ІЧ випромінювач, який в ІЧ ГСН сприймається, як реальна повітряна ціль.

Для імітування просторових, енергетичних та траєкторних ознак повітряної цілі відстрілювання ХТЦ виконується у вигляді комбінованих залпів, у яких ХТЦ мають різну потужність ІЧ випромінювання, різні коефіцієнти лобового опору, завдяки чому швидкість гальмування зустрічним повітряним потоком у них різна, а часові інтервали відстрілювання окремих ХТЦ у залпі підбираються таким чином, щоб амплітудні, спектральні та траєкторні селектори сучасних ІЧ ГСН не змогли однозначно виконати селекцію. За потужністю ІЧ випромінювання ХТЦ у комбінованому залпі повинні відрізнятися у кілька разів, при чому “найслабкіша" ХТЦ у залпі повинна мати потужність випромінювання не менше, ніж потужність ІЧ випромінювання повітряної цілі.

Такі залпи можуть бути реалізовані за допомогою вітчизняних ХТЦ, що мають калібр 26 мм та 50 мм.

Прикладом пристрою викидання, що реалізує комбіновані залпи ХТЦ калібром 26 мм і 50 мм, може слугувати комбінований пристрій викидання “Адрос" КУВ 26-50 [4].

Однією з основних характеристик ХТЦ, що визначає її ефективне застосування для захисту ЛА від керованих ракет з ІЧ самонаведенням, є максимальна або пікова сила випромінювання у заданому діапазоні довжин хвиль.

Для успішного відбиття ракетної атаки необхідно, щоб сила $I_{X Т Ц ~}$ випромінювання ХТЦ перевищувала силу $I_{Л А}$ випромінювання ЛА, який захищається, що можна записати за допомогою наступного виразу:

$$
I_{X Т Ц} \geq k \cdot I_{Л А},
$$

де $k=3 \ldots 5$ - коефіцієнт надійності перенацілювання ІЧ ГСН з ЛА на ХТЦ [5].

Умові (1) повинні відповідати як ХТЦ, що відстрілюються одиночно, так і ХТЦ з максимальною потужністю випромінювання, що відстрілюються у комбінованому залпі. 
Тому, при розробці ХТЦ і визначенні параметрів іiі ІЧ випромінювання для захисту конкретного типу ЛА, визначальними є параметри його ІЧ випромінювання.

Типові значення сили ІЧ випромінювання ЛА різних класів для діапазонів довжин хвиль $\Delta \lambda=2-3$ мкм та $\Delta \lambda=3-5$ мкм приведені в табл. 1 [6].

Таблиця 1

Типові значення сили ІЧ випромінювання ЛА різних класів

\begin{tabular}{|c|c|c|}
\hline \multirow{2}{*}{ Тип ЛА } & \multicolumn{2}{|c|}{ Сила випромінювання, $B m / c p$} \\
\cline { 2 - 3 } & $\Delta \lambda=2-3$ мкм & $\Delta \lambda=3-5$ мкм \\
\hline $\begin{array}{c}\text { Вертоліт (без } \\
\text { засобів зниження } \\
\text { ІЧ помітності) }\end{array}$ & $10 \ldots 100$ & $100 \ldots 300$ \\
\hline $\begin{array}{c}\text { Середній турбо- } \\
\text { гвинтовий літак }\end{array}$ & $20 \ldots 200$ & $200 \ldots 500$ \\
\hline $\begin{array}{c}\text { Тактичний } \\
\text { винищувач }\end{array}$ & $50 \ldots 1000$ & $100 \ldots 6000$ \\
\hline $\begin{array}{c}\text { Важкий транспо- } \\
\text { ртний літак }\end{array}$ & $10 \ldots 1000$ & $100 \ldots 5000$ \\
\hline
\end{tabular}

Джерело: [6].

Найчастіше максимальну силу ІЧ випромінювання ХТЦ, як основну іiі енергетичну характеристику, приводять для діапазону довжин хвиль $\Delta \lambda=3-5$ мкм, у якому функціонують більшість IЧ ГСН сучасних керованих ракет.

Алгоритм розрахунку сили ІЧ випромінювання в інших діапазонах довжин хвиль при фіксації випромінювання за допомогою радіометрів наступний.

Розрахункова формула для визначення сили ІЧ випромінювання по зафіксованим вихідним сигналам $U c(\mathrm{MB})$ прямого каналу вимірювань радіометра для діапазону довжин хвиль $\Delta \lambda=3,0-5,0$ мкм має вигляд:

$$
I_{3,0-5,0}=1,4 \cdot 10^{-8} \frac{Д_{\text {วop }}^{2}}{\tau_{\phi} \tau_{a}} U_{c},
$$

де $Д_{\text {гор }}$ - горизонтальна дальність між наземною апаратурою і ціллю, м;

$\tau_{\phi}-$ коефіцієнт пропускання послаблюючого фільтру;

$\tau_{a}-$ коефіцієнт пропускання атмосфери.

Розрахункова формула для визначення сили ІЧ випромінювання по зафіксованим вихідним сигналам $U c(\mathrm{MB})$ обвідного каналу вимірювань радіометра для діапазону довжин хвиль $\Delta \lambda=3,0-5,0$ мкм має вигляд:

$$
I_{3,0-5,0}=2,1 \cdot 10^{-7} \frac{Д_{2 o p}^{2}}{\tau_{\phi} \tau_{a}} U_{c}
$$

При застосуванні послаблюючих фільтрів для вимірювань ІЧ випромінювання для розрахунків приймають значення коефіцієнту пропускання фільтру $\tau_{\phi}$ відмінне від одиниці [7].

За фактичних метеорологічних умов коефіцієнт пропускання атмосфери для $\Delta \lambda=3,0-5,0$ мкм визначається коефіцієнт пропускання атмосфери $\tau_{a}$ [7].

Для об'єктів, які випромінюють як чорне тіло 3 коефіцієнтом випромінювання $\varepsilon \approx$ const сила випромінювання, яка виміряна в діапазоні $\Delta \lambda=3,0-5,0$ мкм, може бути перерахована для діапазонів довжин хвиль $\Delta \lambda=2,8-4,2$ мкм $\left(I_{2,8-4,2}\right)$ та $\Delta \lambda=2,0-3,0$ мкм $\left(I_{2,0-3,0}\right)$ за розрахунковими формулами:

$$
\begin{aligned}
& I_{2,8-4,2}=I_{3,0-5,0} \frac{\Delta Z_{2,8-4,2}}{\Delta Z_{3,0-5,0}} ; \\
& I_{2,0-3,0}=I_{3,0-5,0} \frac{\Delta Z_{2,0-3,0}}{\Delta Z_{3,0-5,0}},
\end{aligned}
$$

де $I_{3,0-5,0}$ - сила ІЧ-випромінювання для діапазону довжини хвиль $\Delta \lambda=3,0-5,0$ мкм, Вт/ср;

$\Delta Z_{\lambda 1-\lambda 2}$ - щільність ІЧ випромінювання для відповідних діапазонів довжин хвиль $\left(\lambda_{1}-\lambda_{2}\right)$.

При фактичній температурі вихідних газів двигуна $T_{\text {вих }}=300^{\circ} \mathrm{C}=573 \mathrm{~K}$ значення щільності ІЧ випромінювання $\Delta Z_{\lambda 1-\lambda 2}$ становить: $\Delta Z_{2,0-3,0}=0,03$; $\Delta Z_{2,8-4,2}=0,122 ; \Delta Z_{3,0-5,0}=0,213$. Щільність $\Delta Z_{\lambda 1-\lambda 2}$ визначається за методикою, яка викладена в [7 С. 172-182].

Джерелом ІЧ випромінювання ХТЦ є піротехнічний заряд, який згоряє в атмосфері після його запалення та відділення від ЛА.

До складу піротехнічного заряду ХТЦ входять високоенергетичне паливо і ефективний окислювач. Найчастіше у якості палива застосовується дрібнодисперсний порошок магнію $\mathrm{Mg}$, а у якості окислювача - політетрафторетилен $C_{2} F_{4}$. Технічна назва політетрафторетилену - тефлон.

Крім магнію та тефлону до складу піротехнічного заряду у якості цементатора вводять модифікацію тефлону - вітон, який дає змогу формувати піротехнічні заряди необхідної форми шляхом пресування, а піротехнічні заряди, до складу яких як основні компоненти входять магній, тефлон та вітон позначаються як МТВ [8].

Реакція хімічних перетворювань МТВ - сполук без участі атмосферного кисню має вигляд:

$$
2 \mathrm{Mg}+\mathrm{C}_{2} \mathrm{~F}_{4} \rightarrow 2 \mathrm{MgF}_{2}+2 \mathrm{C}+\theta
$$

де $\theta$ - теплотворність реакції.

Теплотворність реакції складає близько $7,5 \cdot 10^{6}$ Дж/к2, а температура продуктів реакції сягає $2000-2200 K$.

3 врахуванням того, що при високій температурі магній може вступати у реакцію окислення 3 атмосферним киснем, у піротехнічному заряді маг- 
ній береться 3 надлишком. Таким чином, у процесі горіння піротехнічного заряду у повітрі, крім реакції (2), додатково надлишковий магній $M g$ та вільний вуглець $C$, що утворюється внаслідок цієї реакції, окислюються атмосферним киснем. Це призводить до додаткового виділення тепла 3 такою ж теплотворністю - близько $7,5 \cdot 10^{6}$ Дж/кг, тобто повне $H_{T}$ тепловиділення сполук МТВ складає біля $15 \cdot 10^{6}$ Дж / к2 .

Теоретична оцінка сили ІЧ випромінювання ХТЦ з застосуванням класичних рівнянь випромінювання чорного тіла пов'язана зі значними труднощами, тому на практиці більш широке поширення отримали емпіричні співвідношення. Силу $I_{X T L}$ випромінювання ХТЦ можна записати у такому вигляді [6]:

$$
I_{X T Ц}=\dot{m} \cdot E_{\lambda}
$$

де $\dot{m}$ - питома масова швидкість згорання матеріалу піротехнічного заряду, кг/c ;

$E_{\lambda}-$ питома енергія випромінювання матеріалу піротехнічного заряду, Дж/(к2·cp), яка визначається за наступною формулою:

$$
E_{\lambda}=\frac{1}{4 \pi} H_{T} \cdot \varepsilon \cdot \Delta Z_{\lambda} \cdot d_{\text {УБЗ }},
$$

де $\varepsilon-$ коефіцієнт випромінювання зовнішньої поверхні факелу горіння ХТЦ, для оціночних розрахунків приймають $\varepsilon=0,75$;

$\Delta Z_{\lambda}-$ відносна щільність випромінювання для заданого діапазону довжин хвиль, зокрема, при вказаних температурах горіння ХТЦ для діапазону $\Delta \lambda=3-5$ мкм, вона приймає значення $\Delta Z_{\lambda}=0,175$;

$d_{\text {УБз }}$ - коефіцієнт, що враховує зміни $E_{\lambda}$ від умов бойового застосування ЛА - висоти $H_{Л А}$ та

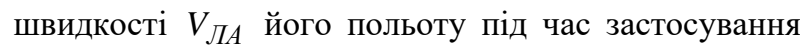
ХТЦ.

Питома масова швидкість згорання матеріалу ХТЦ $\dot{m}$ визначається як хімічними, так і фізичними (щільність, вологість, геометричні розміри та форма) властивостями піротехнічного заряду.

Зокрема, пікові значення цього параметру знаходяться у таких межах: для ХТЦ калібру 26 мм $\dot{m}=0,01-0,02 \kappa 2 / c ;$ для ХТЦ калібру 50 мм $\dot{m}=0,05-0,2 \kappa 2 / c$.

Вплив умов бойового застосування ЛА - висоти $H_{Л А}$ та швидкості $V_{Л А}$ його польоту на енергетичні параметри ХТЦ детально досліджено у багатьох роботах, наприклад [9-10]. Аналіз та узагальнення даних досліджень дає змогу усереднити зна- чення коефіцієнта $d_{У Б 3}$ при застосуванні ХТЦ у різних умовах.

Так, при застосуванні ХТЦ з ЛА фронтової авіації і літаків військово-транспортної авіації (ВТА), коли типовими їх висотами і швидкостями польоту є $H_{Л А}=2000-6000 \mu$ і $V_{Л А}=150-250 \mu / c$, цей коефіцієнт приймає значення $d_{У Б 3}=0,5-0,8$, при застосуванні ХТЦ з ЛА, наприклад вертольотів, для яких $H_{Л А} \leq 1000 м$ та $V_{Л А} \leq 100 м / c$, можна приймати $d_{У Б 3}=1,4-2,0$, а для стаціонарних умов при відстрілюванні ХТЦ з нерухомої наземної установки, що відповідають умовам іiі полігонного тестування, $d_{\text {УБЗ }}=2,0$.

Аналіз виразів (7) і (8) показує, що сила ІЧ випромінювання ХТЦ, створених на основі сполук МТВ, визначається питомою масовою швидкістю згорання матеріалу піротехнічного заряду (параметр $\dot{m})$ і суттєво залежить від умов, при яких виконується відстрілювання ХТЦ (коефіцієнт $d_{У Б з}$ ). Зокрема, при наступних вихідних даних: $\dot{m}=0,1 \kappa 2 / c$; $\varepsilon=0,75 ; H_{T}=15 \cdot 10^{6}$ Дж $/ \kappa 2 ; \Delta Z_{\lambda}=0,175$, для діапазону довжин хвиль $\Delta \lambda=3-5$ мкм, застосовуючи формули (6) та (7), отримаємо, що одна і та ж ХТЦ має наступні значення сили ІЧ випромінювання:

- для стаціонарних умов полігонного тестуван-

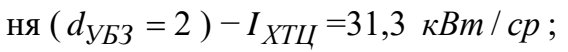

- при застосуванні з вертольота $\left(d_{У Б 3}=1,75\right)-$ $I_{X T Ц}=27,4 \kappa B m / c p$;

- при застосуванні з ЛА фронтової авіації або з

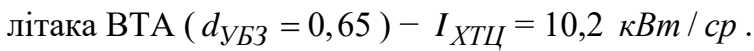

Таким чином, сила ІЧ випромінювання ХТЦ, внаслідок врахування висоти та швидкості польоту ЛА, що захищається, може знижуватися у 3 і більше разів у порівнянні з силою ІЧ випромінювання, отриманою у стаціонарних умовах полігонного тестування. Цей фактор необхідно враховувати при обгрунтуванні енергетичних параметрів ХТЦ для забезпечення ефективного захисту ЛА від ракет з ІЧ самонаведенням у відповідності до умови (1).

Якщо значення сили ІЧ випромінювання ХТЦ не відповідає умові (1), то, у відповідності до виразу (7) на етапі проектування, iіi можна коригувати зміною величини $\dot{m}$, тобто зміною закону горіння піротехнічної сполуки у часі.

Часто при недоцільності або неможливості виконання умови (1) за допомогою однісї ХТЦ, ця умова може виконуватися одночасним відстрілюванням двох і більше ХТЦ.

Крім сили ІЧ випромінювання, до основних характеристик ХТЦ відносяться також часові характеристики випромінювання, такі як: 
- час виходу на режим горіння $\left(t_{\text {реж}}\right)$, під яким розуміють проміжок часу між моментом початку горіння та моментом досягнення заданого рівня випромінювання ХТЦ, який складає 10\% від максимального;

- час досягнення ефективного випромінювання $\left(t_{e \phi}\right)$ - це час від початку горіння, протягом якого сила випромінювання ХТЦ сягає заданого рівня від максимального випромінювання, коли стає можливим найбільш ефективне перенацілювання ІЧ ГСН з ЛА на ХТЦ. Такий рівень складає величину $0,75 \cdot I_{\text {макс }}$

- повний час випромінювання $\left(t_{\text {повн }}\right)$ - проміжок часу між моментами досягнення деякого опорного рівня випромінювання на стадії виходу на режим та зниження випромінювання до цього ж рівня на стадії закінчення горіння ХТЦ. За опорний рівень приймають величину $0,1 \cdot I_{\text {макс }}$;

- закон випромінювання - залежність $I_{X T Ц}(t)$.

Фізичний зміст параметрів $I_{\text {макс }}, t_{\text {реж }}, t_{e \phi}$ та $t_{\text {повн }}$ наведено на рис. 1.

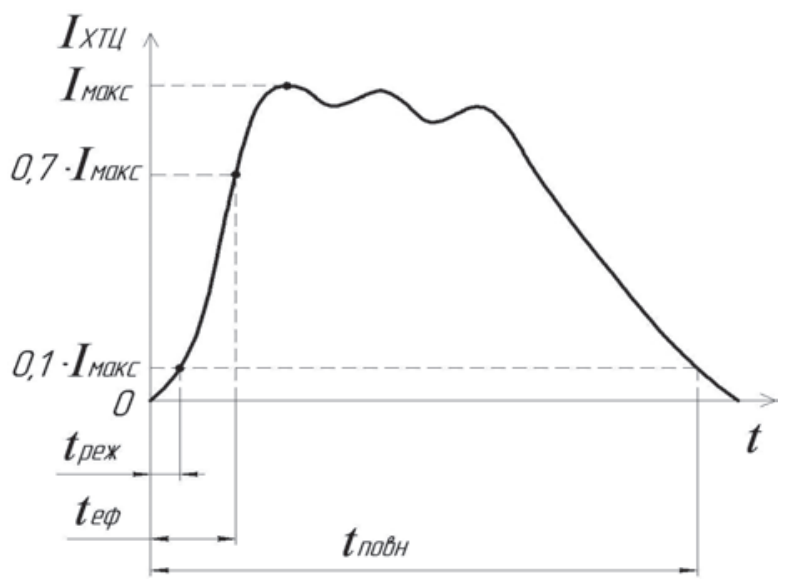

Рис. 1. Фізичний зміст параметрів

$$
I_{\text {макс }}, t_{\text {реж }}, t_{e \phi} \text { та } t_{\text {повн }}
$$

Джерело: розроблено авторами.

За результатами імітаційного моделювання процесу захисту ЛА від ракетних атак за допомогою ХТЦ [3], можна зробити два висновки:

- для досягнення максимальної ефективності захисту ЛА від ракет з ІЧ ГСН за допомогою ХТЦ їх застосування повинно виконуватись на дальностях до атакуючої ракети, що не перевищують $2,0-2.5$ км;

- час знаходження ХТЦ у полі зору ІЧ ГСН, при якому можливе перенацілювання ІЧ ГСН з ЛА на ХТЦ, складає від $t_{\text {мін }}=0,3$ с до $t_{\text {макс }}=0,7$ с від моменту відділення ХТЦ від ЛА.

Перший висновок дозволяє обгрунтувати величину повного часу випромінювання сучасних ХТЦ. При цьому необхідно мати на увазі, що повний час випромінювання ХТЦ повинен бути таким, щоб захоплена ХТЦ відвела координатор ІЧ ГСН атакуючої ракети на такий кут, щоб ЛА вийшов за межі його поля зору.

Результати моделювання показують, що при застосуванні ХТЦ на дальностях до атакуючої ракети не більших, ніж 2,0 - 2.5 км та швидкостях відстрілювання ХТЦ з ЛА біля $30 \mathrm{~m} / \mathrm{c}$, час виходу ЛА за межі поля зору ІЧ ГСН сучасних керованих ракет складає $1,5-2,5$ с.

Тому можна вважати, що повний час випромінювання сучасних ХТЦ повинен бути більшим, ніж 2,5 с. Але, зважаючи на те, що швидкість горіння піротехнічних сполук на основі МТВ при температурах застосування $\pm 50^{\circ} \mathrm{C}$ може відхилятися на величину $\pm 20 \%$ від номінальної [8], можна сфор-

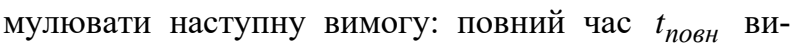
промінювання ХТЦ, при стаціонарних умовах іiі відстрілювання з нерухомої наземної установки і температурі оточуючого середовища $15^{0} \mathrm{C}$, повинен складати не менше, ніж 3,0 с, тобто повинна виконуватися умова $t_{\text {повн }} \geq 3,0$ с.

Другий висновок говорить про те, що перенацілювання ІЧ ГСН на ХТЦ повинно здійснитись у проміжок часу 0,3 - 0,7 с після ії відстрілювання, що дає змогу обгрунтувати такі параметри, як $t_{\text {реж }}$ та $t_{e \phi}$.

Очевидно, що необхідною умовою ефективної дії ХТЦ проти ІЧ ГСН сучасних керованих ракет $є$ $t_{\text {реж }}<0,3 \mathrm{c}$ i $t_{e \phi} \leq 0,7 \mathrm{c}$. Тому при розгляді вимог до сучасних ХТЦ доцільно приймати: $t_{\text {реж }} \leq 0,2 \mathrm{c} \mathrm{i}$ $t_{e \phi} \approx 0,3-0,5 \mathrm{c}$.

Застосуємо також висновок про знаходження ХТЦ у полі зору ІЧ ГСН протягом 0,3 - 0,7 с після іiі відстрілювання, коли виконується перенацілювання ІЧ ГСН з ЛА на ХТЦ, для обгрунтування закону зміни випромінювання ХТЦ у часі $-I_{X Т Ц ~}(t)$.

Закон зміни випромінювання ХТЦ у часі $I_{X Т Ц}(t)$, згідно з (7), визначається законом зміни питомої масової швидкості згорання матеріалу піротехнічного заряду у часі - $\dot{m}(t)$, який, у відповідності до законів внутрішньої балістики, може бути прогресивним, постійним або дегресивним [11-12].

Закони ІЧ випромінювання $I_{X T Ц}(t)$ при прогресивному, постійному та дегресивному горінні піротехнічних зарядів, що мають одинакові маси та час повного випромінювання, зображені на рис. 2. 


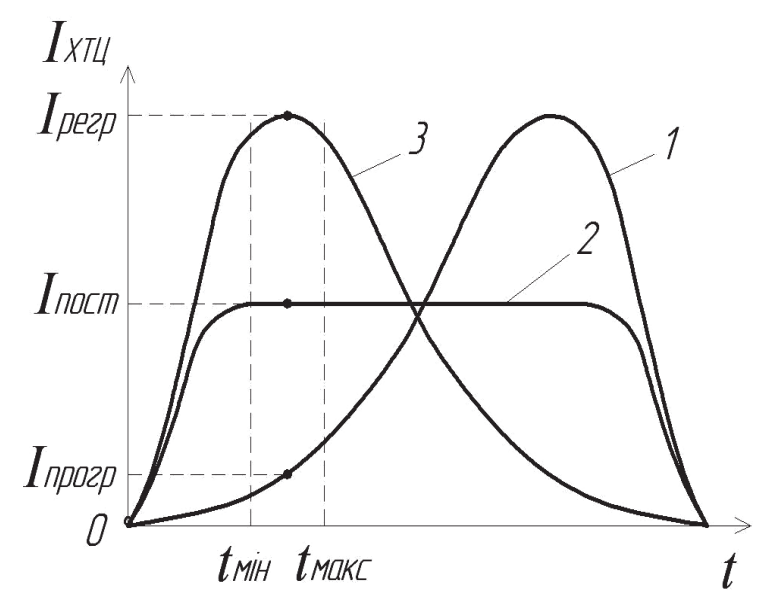

Рис. 2. Закони випромінювання $I_{X т Ц}(t)$ при горінні заряду:

1 - прогресивному;

2 - рівномірному,

3 - регресивному

Джерело: розроблено авторами.

Як свідчить рис. 2, при прогресивному та дегресивному законах горіння досягаються значно більші максимальні значення $I_{\text {макс }}$, ніж при постійному законі горіння піротехнічного заряду. Але, якщо розглядати час досягнення максимального ІЧ випромінювання ХТЦ, то у необхідний проміжок часу $\left(t_{\text {мін }} \ldots t_{\text {макс }}\right)$ справедливим $\epsilon$ наступне співвідношення:

$$
I_{\text {прогр }}<I_{\text {nост }}<I_{\text {регр }},
$$

де: $I_{\text {прогр }}, I_{\text {пост }}, I_{\text {регр }}-$ значення сили випромінювання у середній частині проміжку часу $\left(t_{\text {мін }} \ldots t_{\text {макс }}\right)$ для піротехнічних зарядів ХТЦ, що мають прогресивний, постійний та регресивний закон горіння, відповідно.

Порівнюючи значення сили ІЧ випромінювання при цих законах горіння, приходимо до висновку, що найбільш ефективним законом горіння матеріалу піротехнічного заряду ХТЦ є дегресивний, при якому у проміжок часу $t_{\text {мін }} \ldots t_{\text {макс }}$ досягаються значно більші значення $I_{X T Ц}$, ніж при постійному та прогресивному законах горіння, що максимально сприяє процесу перенацілювання ІЧ ГСН з ЛА на ХТЦ.

Прикладом сучасних ХТЦ, які відповідають викладеним вимогам, можуть слугувати МТВ ХТЦ “Адрос" ПІК-50 і “Адрос” ПІК-26, що мають калібр 50 мм та 26 мм, відповідно (розробка НВФ “Адрон”, м. Київ).

На рис. 3 і 4 представлено закони випромінювання МТВ ХТЦ “Адрос” ПІК-50 і “Адрос” ПІК-26 калібру 50 мм та 26 мм відповідно, які отримані в стаціонарних умовах полігонного тестування.

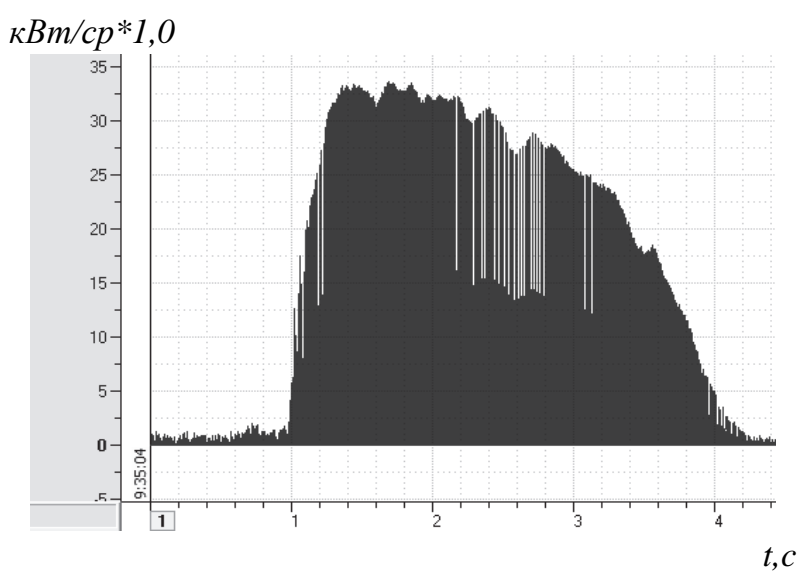

Рис. 3. Закон випромінювання ХТЦ типу "Адрос" ПІК-50

Джерело: розроблено авторами.

Як свідчать рис. 3 та рис. 4, МТВ ХТЦ типу “Адрос” ПІК-50 та “Адрос" ПІК-26 мають дегресивний закон горіння піротехнічного заряду з наступними характеристиками: для ХТЦ “Адрос” ПІК-50: $I_{\text {макс }}=33 \kappa \mathrm{Bm} / \mathrm{cp}, t_{\text {реж }}<0,2 \mathrm{c}, t_{\text {еф }} \approx 0,3 \mathrm{c}, t_{\text {повн }}>$ $3 \mathrm{c} ;$ для ХТЦ "Адрос" ПІК-26: $I_{\text {макс }}=3,1 \kappa B m / c p, t_{\text {реж }}<0,2 \mathrm{c}, t_{e \phi} \approx 0,3 \mathrm{c}$, $t_{\text {повн }}>3 \mathrm{c}$.

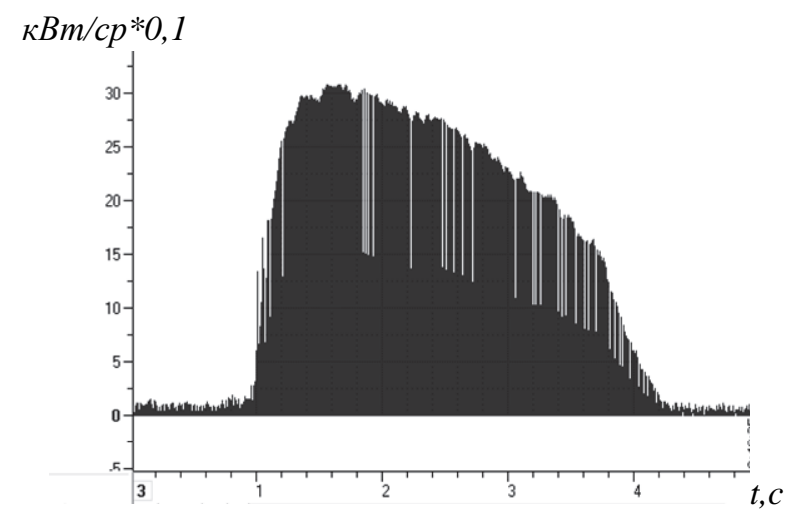

Рис. 4. Закон випромінювання ХТЦ типу “Адрос" ПІК-26

Джерело: розроблено авторами.

\section{Висновки}

Обгрунтовано вимоги до сучасних зразків ХТЦ, що створюються на основі магній-тефлон-вітонових сполук, основними з яких є наступні: час виходу на режим горіння повинен бути меншим, ніж $0,2 \mathrm{c}$; час досягнення ефективного випромінювання повинен складати $0,3-0,5 \mathrm{c}$; повний час випромінювання ХТЦ повинен бути не меншим, ніж 3,0с.

Найбільш ефективним законом горіння матеріалу піротехнічного заряду ХТЦ є дегресивний, при якому протягом короткого часу $(0,3-0,5$ с) досяга- 
ються максимальні значення пікової сили ІЧ випромінювання, що максимально сприяє процесу перенацілювання ІЧ ГСН з ЛА на ХТЦ.

Вітчизняні розробки у галузі створення нових зразків ХТЦ, за максимальними значеннями сили ІЧ випромінювання та часовими параметрами випромінювання повністю відповідають сучасним вимогам до ХТЦ і забезпечують високий рівень захисту ЛА від керованих ракет з ІЧ самонаведенням.

\section{Список літератури}

1. Мишук М.Н. Защита самолетов от ракет с тепловыми головками самонаведения / М.Н. Мишук. - М.: Военное издательство, 1982. - $384 \mathrm{c.}$

2. Брыксин С.В. Состояние и перспективы пиротехнических средств защиты летательных аппаратов от высокоточного оружия / С.В. Брыксин, Е.П. Поляков, С.Н. Вагонов // Известия Тульского Государственного университета. - 2014. - № 12. - С. 199-204.

3. Бельский А.Б. Направления совершенствования систем оптико-электронного противодействия летательных аппаратов ракетам с оптическими головками самонаведения / А.Б. Бельский, В.М. Чобан. - М.: Авиационная техника и технология. - 2014. - № 1. - С. 32-39.

4. Кравчук І.С. Інфрачервоне протистояння / І.С. Кравчук // Український оборонний вісник. - 2019. - № 7. - С. 48-51.

5. Якушенков Ю.Г. Методы борьбы с помехами в оптико-электронных приборах / Ю.Г. Якушенков, В.Н. Луканцев, М.П. Колосов. - М.: Радио и связь, 1981. - 180 с.

6. Neal Brune. Expendable Decoys. The Infrared \& Electro-Optical Systems Handbook / Brune Neal. - USA. ERIM/SPIE PRESS, 1993. - $520 \mathrm{p}$.

7. Криксунов Л.З. Справочник по основам инфракрасной технике / Л.З. Криксунов. - М.: Сов. радио, 1978. - 182 с.

8. Koch Ernst-Chrisnian. Metal-Fluorocarbon Based Energetic Materials [Electronic resource] / Ernst-Chrisnian Koch. 2012. - 360 p. - Available at: https://www.wiley.com/en-ua/Metal+Fluorocarbon+Based+Energetic+Materials-p-9783527329205.

9. Towning J.N. Pyrotechnic flares: radiant intensity and radiance calculations / J.N. Towning // 14-th International Pyrotechnics Seminar. - Jersey, UK, 18-22 September 1989. - P. 537.

10. Air flow test facility for investigation of pyrotechnical decoy / L. Deimbling, A. Blanc, G. Billeb, T. Klahn // 41-st International Annual Conference of ICT. - Karlsruhe, Germany, 29 June-2 July 2010. - P. 127.

11. Кувеко А.Е. Внутренняя баллистика ствольных систем и ракетные двигатели твердого топлива / А.Е. Кувеко, Ф.П. Миропольский. - М.: ВВИА им. Н.Е. Жуковского, 1987. - 312 с.

12. Серебряков М.Е. Внутренняя баллистика ствольных систем и порохових ракет / М.Е. Серебряков. - М.: Государственное научно-техническое издательство Оборонгиз, 1962. - 705 с.

\section{Відомості про авторів:}

\section{Кравчук Ілля Степанович}

кандидат технічних наук доцент

начальник науково-дослідного відділу товариства

з обмеженою відповідальністю

“Науково-виробнича фірма “Адрон””,

Київ, Україна

https://orcid.org/0000-0002-1053-7798

\section{Сподін Олександр Іванович}

провідний конструктор товариства

3 обмеженою відповідальністю

"Науково-виробнича фірма “Адрон”",

Київ, Україна

https://orcid.org/0000-0002-9843-1145

\section{Нікітченко Віктор Іванович}

кандидат технічних наук

начальник науково-дослідного відділу

Державного науково-дослідного інституту випробувань і сертифікації озброєння та військової техніки,

Чернігів, Україна

https://orcid.org/0000-0001-8973-8711

\section{Information about the authors:}

\section{Illya Kravchyk}

Candidate of Technical Sciences

Associate Professor

Chief of Scientific Research Department

of Adron Research and Development Co. Ltd.,

Kyiv, Ukraine

https://orcid.org/0000-0002-1053-7798

\author{
Alexander Spodin \\ Lead Designer \\ of Adron Research \\ and Development Co. Ltd. \\ Kyiv, Ukraine \\ https://orcid.org/0000-0002-9843-1145
}

\section{Viktor Nikitcnenko}

Candidate of Technical Sciences

Chief of Scientific Research Department

of State Scientific Research Institute of Armament and Military Equipment Testing and Certification,

Chernihiv, Ukraine

https://orcid.org/0000-0001-8973-8711 
Березанський Володимир Григорович

кандидат технічних наук

доцент кафедри

Харківського національного університету

Повітряних Сил ім. І. Кожедуба,

Харків, Україна

https://orcid.org/0000-0003-3753-0016
Volodymyr Berezanskyi

Candidate of Technical Sciences

Senior Lecturer

of Ivan Kozhedub Kharkiv

National Air Force University,

Kharkiv, Ukraine

https://orcid.org/0000-0003-3753-0016

\title{
ОБОСНОВАНИЕ ПАРАМЕТРОВ ЛОЖНЫХ ТЕПЛОВЫХ ЦЕЛЕЙ ДЛЯ ЗАЩИТЫ ЛЕТАТЕЛЬНЫХ АППАРАТОВ ОТ УПРАВЛЯЕМЫХ РАКЕТ С ИНФРАКРАСНЫМ САМОНАВЕДЕНИЕМ
}

\author{
И.С. Кравчук, А.И. Сподин, В.И. Никитченко, В.Г. Березанский
}

В статье обоснованы требования к современным ложным тепловым целям для защиты летательных аппаратов от управляемых ракет с инфракрасным самонаведением. Проведен анализ алгоритмов помехозащишенности, которые реализованы в инфракрасных головках самонаведения. Определено, что очень часто для реализации алгоритмов помехозащищенности в инфракрасных головках самонаведения последних поколений применяется метод слежения за “ближайшей” тепловой целью. Суть метода состоит в следуюшем: в каждом периоде сканирования сохраняются поточные амплитуда сигнала и координаты, которые соответствуют воздуиной иели. Учитывая тот факт, что амплитуда сигнала и координаты ложной тепловой иели изменяются намного быстрее, нежели эти же параметры воздушной иели, при появлении в поле зрения инфракрасной головки самонаведения двух источников инфракрасного излучения, то за иель принимается источник, амплитуда сигнала и координаты которого ближайшие к значениям, которые были в предварительном периоде сканирования. Таким образом, ключом к значительному повышению эффективности зашиты летательных аппаратов с помощью ложных тепловых целей есть усовершенствование способов их применения. Также в современных комплексах защиты летательных аппаратов от управляемых ракет с инфракрасными головками самонаведения наметился переход к массовому отстрелу ложных тепловых целей в виде залпов, когда инфракрасное излучение цели “растворяется” на фоне одной или нескольких “туч” ложных излучателей. Этот способ применения ложных тепловых иелей очень эффективный, но требует большого количества их на борту летательного аппарата. В статье показано, что для имитации пространственньх, энергетических и траекторных признаков воздушной цели отстрел ложных тепловых целей проводится в виде комбинированных залпов, у которых ложсые тепловые цели имеют различную мощчность инфракрасного излучения, различные коэффициенть лобового сопротивления, благодаря чему скорость торможения встречным воздушным потоком у них различная, а временные интерваль отстрела отдельных ложных тепловых иелей в залпе подбираются таким образом, чтобы амплитудные, спектральные и траекторные селекторы современных инфракрасных головок самонаведения не смогли однозначно произвести селекиию. Подтверждено, что одной из основных характеристик ложных тепловых иелей, которая определяет эффективность их применения для защиты летательных аппаратов от управляемых ракет с инфракрасными головками самонаведения, есть максимальная или пиковая сила излучения в заданном диапазоне длин волн. Также в статье рассмотрен один из новых способов применения ложных тепловых цеелей и выдвинуты требования к этому способу. Также обоснованы требования к закону изменения инфракрасного излучения во времени, необходимой сильл инфракрасного излучения, времени выхода на режим и достижения эффективного уровня излучения, а также полного времени излучения.

Ключевые слова: ошибочная тепловая цель, летательный аппарат, сила излучения, магний-тефлон-витон, время выхода на режим, закон изменения излучения.

\section{GROUND OF PARAMETERS OF FALSE THERMAL AIMS FOR PROTECTING OF AIRCRAFTS FROM THE GUIDED ROCKETS WITH INFRA-RED HOMING}

\section{Kravchyk, A. Spodin, V. Nikitcnenko, V. Berezanskyi}

In the article requirements are reasonable to the modern false thermal aims for protecting of aircrafts from the guided rockets with the infra-red homing. The analysis of algorithms of noise immunity, which are realized in the infra-red heads of homing, is conducted. It is certain that very often for realization of algorithms of noise immunity in the infra-red heads of homing of the last generations the method of track is used after the "nearest" thermal aim. Essence of method consists of the following: in every period of scan-out stream is saved amplitude of signal and co-ordinates which answer the air purpose. Taking into account circumstance that amplitude of signal and co-ordinate of false thermal aim change far quicker than the same parameters of air aim, at appearance in sign of infra-red head of homing of two sources of infrared, then a source sets to the aim, amplitude of signal and the co-ordinates of which are the nearest to the values which were in the preliminary period of scan-out. Thus, by the key to the considerable increase of efficiency of defense of aircrafts by means of false thermal aims there is an improvement of methods of their application. Also, in the modern complexes of defense of aircrafts from the guided rockets with the infra-red heads of homing a transition was set to the mass game shooting of false thermal aims as volleys, when the infrared of target "dissolves" on a background one or a few "clouds" of false emitters. This method of application of false thermal aims is very effective, but requires a generous amount them aboard an aircraft. It is shown in the article, that for the imitation of spatial, power and trajectory sign of air target the game shooting of false thermal aims is conducted as the combined volleys, at which false thermal aims have different power of infrared, different coefficients of head-resistance, due to what braking speed by the meeting current of air for them different, and the temporal intervals of the game shooting of separate false thermal aims in a volley sneak up thus what peak, spectral and trajectory path selectors of modern infra-red heads of homing was not able simply to produce a selection. It is confirmed that one of basic descriptions of false thermal aims, which determines efficiency of their application for protecting of aircrafts from the guided rockets with the infra-red heads of homing, is maximal or spades force of radiation in the set range of lengths of waves. Also in the article one of new methods of application of false thermal aims is considered and requirements are pulled out to this method. Also reasonable requirement to the law of change of infrared in time, necessary force of infrared, time of exit on the mode and achievements of effective level of radiation, and also complete time of radiation.

Keywords: erroneous thermal target, aircraft, radiation strength, magnesium-teflon-viton, time to reach the regime, the law of radiation change. 